\title{
Characterization of Dislocation Structure in a Nb-bearing Austenitic Stainless Steel After Low Cycle Fatigue via TEM and EBSD
}

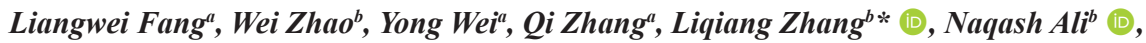 \\ Hongwei Zhou ${ }^{a, c}\left(\mathbb{D}\right.$, Hailian Wei ${ }^{a}$ \\ ${ }^{a}$ Anhui University of Technology, School of Materials Science and Engineering, 243002, Maanshan, \\ China. \\ ${ }^{b}$ Anhui University of Technology, School of Metallurgical Engineering, 243032, Maanshan, China. \\ ${ }^{c}$ Yanshan University, State Key Laboratory of Metastable Materials Science and Technology, 066004, \\ Qinhuangdao, China.
}

Received: August 04, 2021; Revised: November 01, 2021; Accepted: November 04, 2021

In this paper, the relationship between Kernel average misorientation (KAM), geometrically necessary dislocation (GND) density and dislocation structures of Nb-bearing austenitic stainless steel under low cycle fatigue (LCF) was studied at $600^{\circ} \mathrm{C}$ at the total strain amplitude ranged from $0.3 \%$ to $1.0 \%$. The results based on EBSD analysis show that the GND density in fatigue specimens gradually increases with the increase of strain amplitude. Under LCF loading, the dislocation structures are mainly planar slip bands (PSBs) and the cell structures. With the increase of strain amplitude, the number of PSBs increases with decrease in width, and the average diameter of cells also decreases. The PSBs originate due to the dynamic strain aging (DSA) effect, and DSA is more significant under high strain amplitude. The average diameter of cell structures has a specific relationship with GND density.

Keywords: austenitic heart-resistant steel, low-cycle fatigue, EBSD, geometrically necessary dislocation, dislocation structure.

\section{Introduction}

Austenitic stainless steels (ASS) exhibit complex dislocation structures under fatigue, creep, and creep-fatigue interaction condition, which are mainly the cellular structure ${ }^{1-4}$, channel/wall structure, persistent slip bands ${ }^{5,6}$, vein/labyrinth dislocation structures ${ }^{7}$, ladder structure ${ }^{8}$, planar slip bands ${ }^{9}$, the corduroy structure ${ }^{10}$. There are two main slip modes of dislocation in ASS under plastic deformation known as the cross slip and the planar slip. The main factors which influence the slip modes are alloying elements and content, stacking fault energy, deformation temperature and deformation strain rate. According to the previous literature reports ${ }^{2-4,7-10}$, cells and planar structures are mainly formed by dislocation cross slip and dislocation planar slip respectively.

Cells and planar sliding band (PSB) structures are two typical structures of ASS during low -cycle fatigue (LCF) loading, which have the characteristics of deformation localization. The dislocation density in the cell is extremely low, while in the cell walls and PSBs is high. In the past, these were characterized by transmission electron microscopy (TEM) and electron channeling contrast (ECC). In recent years, electron backscatter diffraction (EBSD) has been used to analyze the cells, sub-grains ${ }^{11,12}$, and other dislocation microstructures ${ }^{13,14}$. In particular, the Kernel average misorientation $(\mathrm{KAM})^{15}$, grain reference orientation deviation $(\mathrm{GROD})^{16,17}$, and grain orientation spread $(\mathrm{GOS})^{18}$ are obtained

*e-mail: zhangsir508@163.com from the grain orientation via EBSD measurements, which can be used to qualitatively evaluate the degree of plastic deformation within the grains ${ }^{19}$. KAM focuses on the local misorientation gradients, while the geometrically necessary dislocation (GND) can obtain from the KAM value $\mathrm{K}^{3,8,15,20}$. GROD appears as a hybrid approach, which measures the local misorientations at a grain scale. Finally, GOS focus on the strain distribution gradients at the microstructure scale ${ }^{18}$.

The dislocation cell size in 304 LN ASS was determined by using the KAM and GND maps, and cells were found to be in the range of $0.5 \mu \mathrm{m}^{3}$. GND density was estimated by EBSD characterization, which followed a concave up variation with the plastic strain. Dislocation evolution was analyzed via EBSD studies on various modes of cyclic deformation at $923 \mathrm{~K}$ in a type $316 \mathrm{LN} \mathrm{ASS}^{21}$. The KAM image based on EBSD revealed the evolution of substructure, which revealed the cells formation. The average cell size of $\sim 1 \mu \mathrm{m}$ is obtained through EBSD and is consistent with the TEM observation. The fraction of small subgrains increases with strain while the fraction and size of large subgrains decrease with strain in $316 \mathrm{~L}$ steel analyzed by EBSD characterization ${ }^{11,12}$. Rui et al. ${ }^{16}$ used GROD from EBSD analysis to estimate the creep strain and creep damage. It was found that there existed a linear correlation between the grain lattice distortion parameter (GROD) obtained from EBSD analysis and the creep strain, while it is independent of the creep conditions (stress \& temperature) and average grain size. 
In our previous research work ${ }^{9}$, it was found that the PSBs and cellar structures coexist in Nb-bearing ASS during LCF. $\mathrm{Nb}$, as an important alloy element in new austenitic heat-resistant steel can easily form $\mathrm{NbX}(\mathrm{X}=\mathrm{C}, \mathrm{N})$ particles during high temperature aging or deformation ${ }^{9,22}$, which plays a role for precipitation strengthening. Meanwhile, the strong binding force between $\mathrm{Nb}$ and $\mathrm{C}$ reduces the precipitation of $\mathrm{M}_{23} \mathrm{C}_{6}$ at grain boundary. The pinning of $\mathrm{Nb}, \mathrm{Cr}$ and $\mathrm{Ni}$ on dislocation slipping also induced dynamic strain ageing (DSA) effect ${ }^{22}$, which restrains dislocation cross-slipping. Therefore, planar dislocation structures have been associated with DSA.

In this paper, the PSBs and cells microstructures under LCF loading at high temperature were studied by EBSD and TEM. The relationship between KAM, GND and dislocation microstructure was analyzed.

\section{Experimental Materials and Methods}

The investigated material was a commercial Nb-bearing TP347H ASS pipes for power plants provide by Taiyuan Iron and Steel Group Co., Ltd. China. The chemical composition of TP347H ASS is shown in Table 1. The specimens were solution-treated (ST) at $1100{ }^{\circ} \mathrm{C}$ for 1 hour and followed by water quenching.

The cylindrical specimens with the diameter of $12 \mathrm{~mm}$ were cut from the axial direction of the stainless-steel pipes. After that, the specimens were machined with $18 \mathrm{~mm}$ gauge length and $6 \mathrm{~mm}$ gauge diameter for LCF testing. The specimen surface was polished along the longitudinal direction with the emery paper down to \#1000 in order to remove the surface defects. Fatigue tests were carried out in open air environment under a fully-reversed strain control mode at a constant strain rate of $3 \times 10^{-3} \mathrm{~s}^{-1}$ at $600{ }^{\circ} \mathrm{C}$. The total strain amplitude $(\Delta \varepsilon \mathrm{t})$ ranged from $0.3 \%$ to $1.0 \%$, using a Shimadzu IEHF-EM200k1-070-0A testing system.

Zeiss Sigma 500 scanning electron microscope (SEM) equipped with EBSD camera from Oxford Instruments was performed to study the grain orientation distribution and KAM in samples before and after the fatigue. EBSD testing with a step size of $0.5 \mu \mathrm{m}$ was operated at $20 \mathrm{kV}$. The EBSD data was generated by using the Channel $5^{\mathrm{TM}}$ software. A FEI Talos F200X Scanning TEM examinations with the operating voltage of $200 \mathrm{kV}$ was used to investigate the dislocation sub-structures and carbides under LCF conditions. The thin slices were cut at a distance of $2 \mathrm{~mm}$ away from the fracture surface for TEM and EBSD analysis. EBSD samples were prepared by mechanical polishing and electropolishing $\left(15 \%\right.$ acetic acid $+85 \%$ methanol, $0{ }^{\circ} \mathrm{C}$, $20 \mathrm{~V}$ for $30 \mathrm{~s}$ ). After mechanical polishing, TEM foils with a diameter of $3 \mathrm{~mm}$ and a thickness of $50 \mu \mathrm{m}$ were obtained by ion thinning.

\section{Results and Discussion}

\subsection{Microstructure of the steel after solution-treatment}

The structures of the ST sample are shown in Figure 1. Figures 1(a-b) are EBSD images, while the others are TEM ones. The average grain size is $27 \mu \mathrm{m}$, and there are quite few twins within the grains (marked by red lines) as shown in Figure 1(b). It can be observed in Figure 1(c) that the dislocation intensity inside the grains is low due to a high temperature solution treatment. At the same time, there are still a few carbides with the average size of $1 \mu \mathrm{m}$ as shown in Figure 1(d), which is proved to be primary $\mathrm{NbC}$ particles by EDS mapping in Figures 1(e-f).

\subsection{Fatigue life and cyclic stress}

Figure 2(a) shows the LCF life $\left(N_{f}\right)$ under different strain amplitudes ranging from $0.3 \%$ to $0.9 \%$, which reveals that the fatigue life decreases with the increase of strain amplitude. Figure 2(b) shows the relationship between cyclic stress amplitudes (at half-life) and strain amplitudes which indicates the increases of stress amplitude with increasing the strain amplitude. The fatigue life of TP347H ASS at room temperature (RT) $)^{23}$ and $550{ }^{\circ} \mathrm{C}^{24}$ is listed in Figure 2(a). It is found that, the fatigue life decreases with the increase of temperature. The influence of high temperature on fatigue life of materials is complicated. The previous results of $\mathrm{LCF}$ at RT and $550^{\circ} \mathrm{C}$ showed that DSA effect appeared at $550{ }^{\circ} \mathrm{C}$, and significantly reduced fatigue life ${ }^{25}$. The DSA effect mainly manifests itself as serrated yielding in the stressstrain curves ${ }^{22,25,26}$. Figure 2(c) shows the serrated yielding in hysteresis loop, which indicates that DSA happens under LCF loading at $600{ }^{\circ} \mathrm{C}$. Therefore, DSA is one of the reasons for fatigue life reduction at $600^{\circ} \mathrm{C}$. At the same time, at higher temperature, the oxidation of materials is more serious, which accelerates crack propagation and shortens fatigue $\operatorname{life}^{27}$. At $600^{\circ} \mathrm{C}, \mathrm{TP} 347 \mathrm{H}$ ASS has a higher fatigue life than $316 \mathrm{LN}$ steel with 0.22 wt. $\% \mathrm{~N}^{28}$ at low strain amplitude $(\leq 0.55 \%)$, while at high strain amplitude $(\geq 0.5 \%)$, TP347H ASS has a slightly lower fatigue life than $316 \mathrm{LN}$ steel.

\subsection{Microstructure characterization based on EBSD}

Figure 3 displays the EBSD maps at the fractured region of the sample after LCF loading. The inverse pole figure (IPF) and KAM maps are illustrated in Figure 3(a1,b1,c1) and $(\mathrm{a} 2, \mathrm{~b} 2, \mathrm{c} 2)$, respectively. The IPF and KAM maps are generally used to show the crystal orientation and local misorientation analysis respectively ${ }^{13,14}$. At the bottom of Figure 3, blue and red colors in the color bar of misorientation map indicates the low and high misorientation respectively. KAM maps show an increasing misorientation with the increase of total strain amplitude applied in the fatigue

Table 1. Chemical composition of TP347H steel (wt.\%).

\begin{tabular}{ccccccccccccc}
\hline Element & $\mathrm{C}$ & $\mathrm{N}$ & $\mathrm{P}$ & $\mathrm{S}$ & $\mathrm{Cr}$ & $\mathrm{Ni}$ & $\mathrm{Mo}$ & $\mathrm{Mn}$ & $\mathrm{Si}$ & $\mathrm{Nb}$ & $\mathrm{Fe}$ \\
\hline $\mathrm{wt} \%$ & 0.05 & 0.013 & 0.0181 & 0.006 & 18.36 & 11.53 & 0.890 & 1.07 & 0.53 & 0.815 & $\mathrm{Balance}$ \\
\hline
\end{tabular}




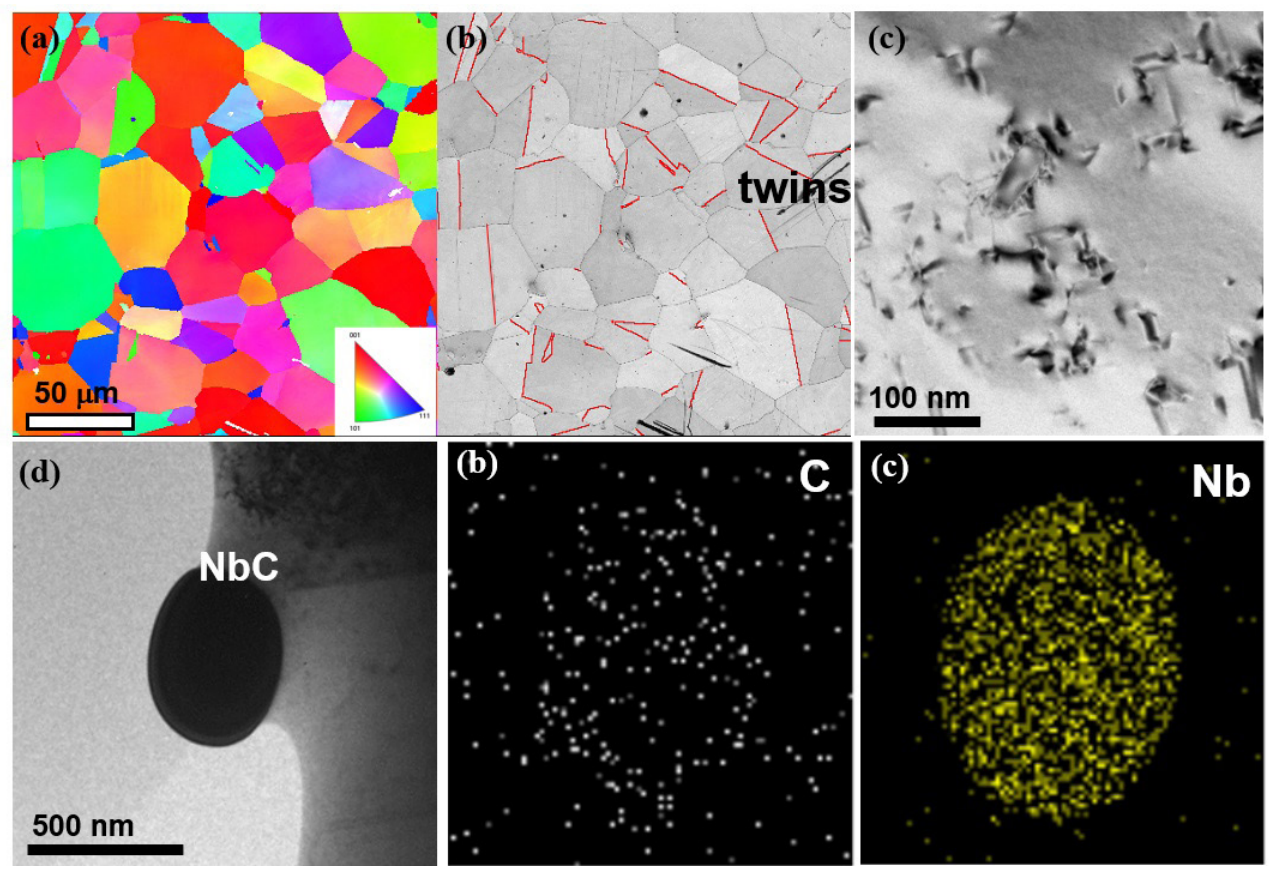

Figure 1. Solution treated sample of TP347H steel. (a) Inverse Pole Figure (IPF) map, (b) Twins remarked by red lines; (c) TEM image; (d) a NbC particle and EDS mapping; (e)-(f) $\mathrm{C}$ and $\mathrm{Nb}$ mapping, respectively.
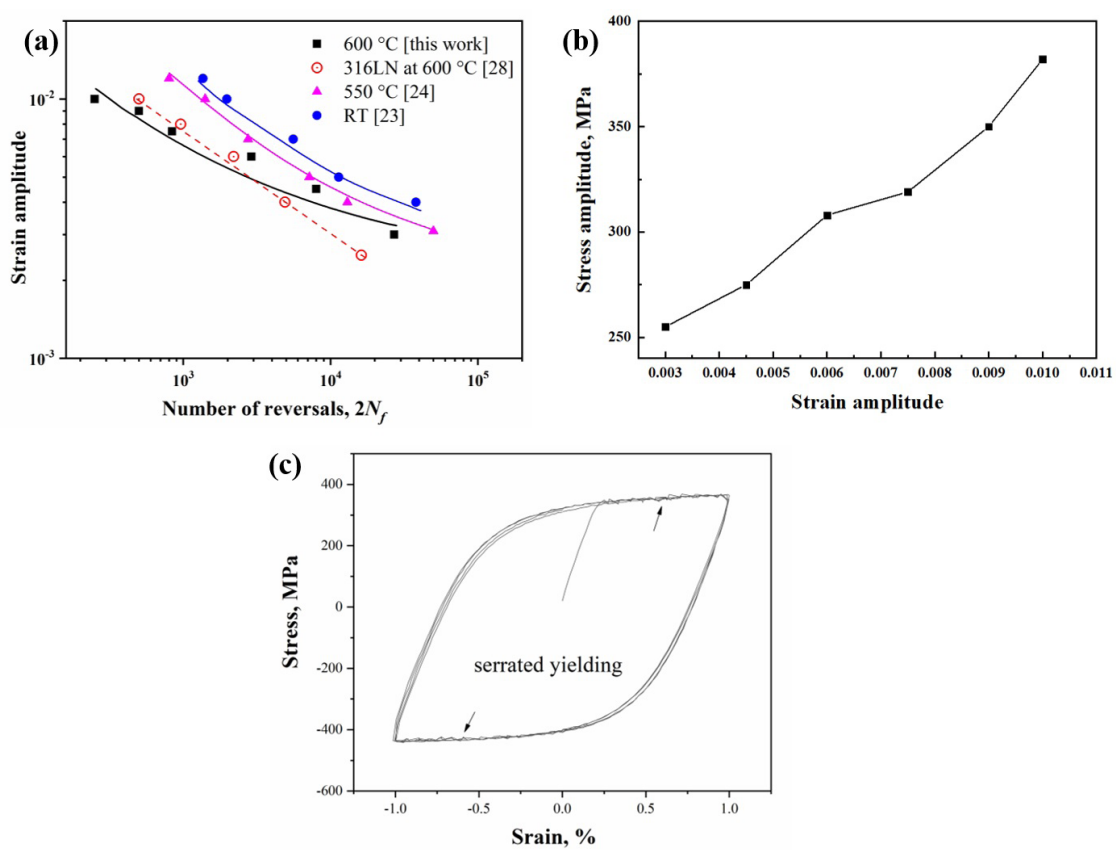

Figure 2. (a) Fatigue life, (b) cyclic stress amplitudes with total strain amplitudes, (c) serrated yielding in the hysteresis loop.

specimens. At $\Delta \varepsilon_{t}=0.3 \%$, most grains were blue and a few green regions appeared around the grain boundaries (GBs), indicating the low KAM value as shown in Figure 3(a2). At $\Delta \varepsilon_{t}=0.6 \%$, most grains appear green, and a few regions around the GBs have yellow color, which indicated that the KAM value increased in these regions as shown in Figure 3(b2). Figure 3(c2) showed that when $\Delta \varepsilon_{\mathrm{t}}$ increased to $0.9 \%$, the green regions increased rapidly, and the red regions also appeared, indicating that the local strain was further increased as compared with $\Delta \varepsilon_{\mathrm{t}}=0.3 \%$ and $0.6 \%$.

Figure 4(a) shows the maps of local misorientation distribution (KAM). The mean misorientation of each given point relative to adjacent points up to $5^{\circ}$ is calculated, and the higher angles more than $5^{\circ}$ are excluded. The KAM 


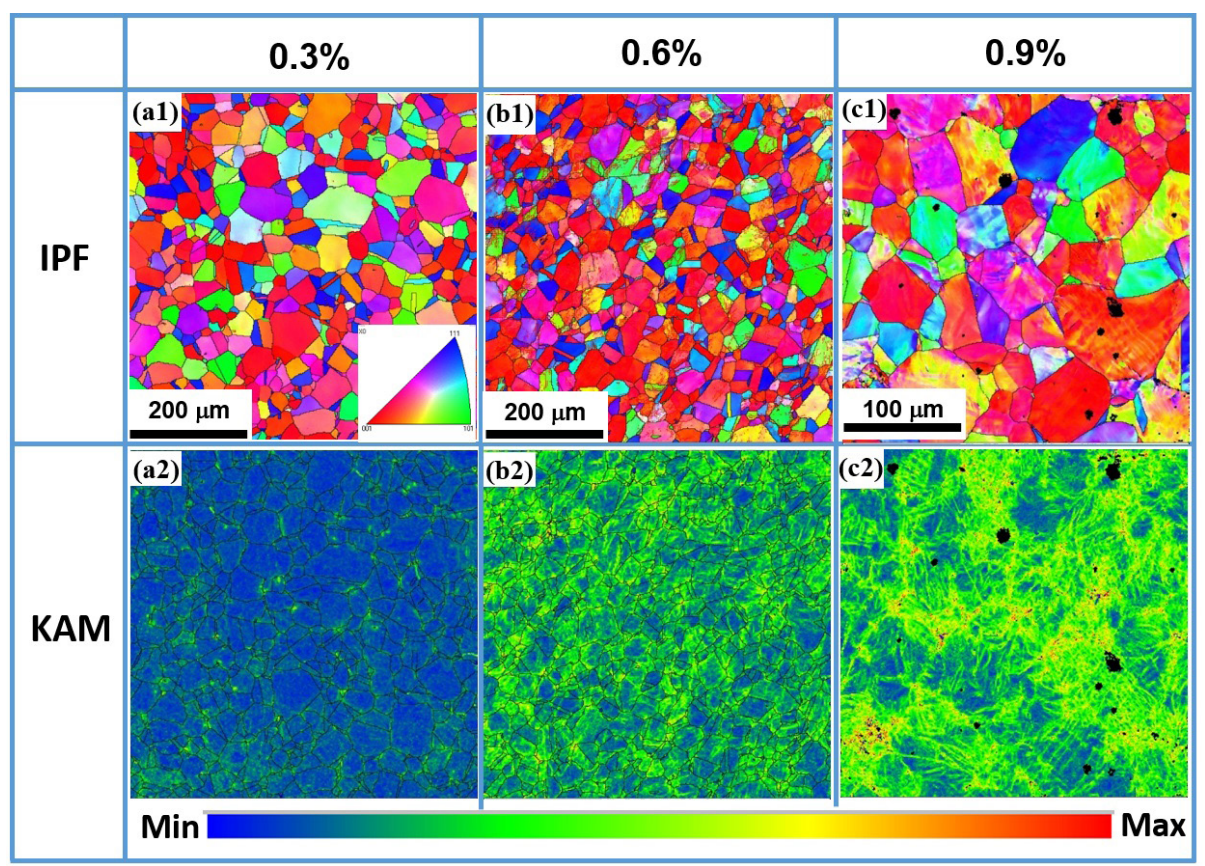

Figure 3. EBSD analysis on the fatigue samples at $\Delta \varepsilon_{\mathrm{t}}=0.3 \% ; 0.6 \% ; 0.9 \%$, (a1)-(c1) IPF maps, (a2)-(c2) KAM maps.
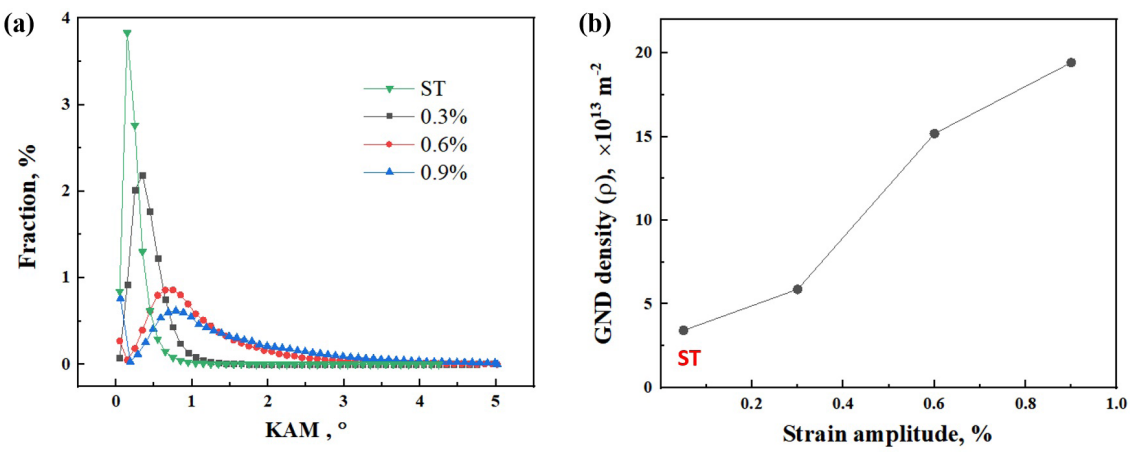

Figure 4. (a) Distribution of KAM value in fatigued samples determined by EBSD analysis from Figure 3; (b) GND density with different strain amplitudes.

peak shifts to higher angles with the increase of total strain amplitudes. The fatigue samples show higher KAM values compared with the ST sample before LCF loading. This result agrees with the both tensile and fatigue samples of 304 and $316 \mathrm{ASS}^{29}$.

The GND is known to be proportional to the average value of $\mathrm{KAM}^{21,30}$. The calculation of GND density can be written as follow, based on the references ${ }^{15,20}$.

$\rho^{G N D}=\frac{2 \theta}{\mu b}$

Where $\rho^{\mathrm{GND}}$ is the GND at points of interest, $\theta$ represents the local misorientation angle in radians, $b$ is the Burger's vector $\left(b=\frac{\sqrt{2}}{2} a_{\gamma}=0.255 \mathrm{~nm}=2.55 \times 10^{-10} \mathrm{~m}, a_{\gamma}=0.361 \mathrm{~nm}\right.$ for austenitic stainless steel) and $u$ is the unit length $(500 \mathrm{~nm})$ of the point.

The variation of average GND with strain amplitudes based on Equation (1) is demonstrated in Figure 4(b). When cyclic loading was applied, the GND density increased with the total strain amplitudes. Hence, the stress required for the dislocation motion was increased, which led to an increase of cyclic stress as shown in Figure 2(b). This result is consistent with other work on Sanicro $25 \mathrm{ASS}^{31}$. A close linear relationship between the GND density with strain amplitude was found in $304 \mathrm{ASS}^{8}$.

Figure 3 (c2) shows that the most parts in the tested specimens are green and red, while there are still some blue ones. This means that the distribution of local misorientation is highly non-uniform, indicating very high localized deformation in the fatigue samples. Compared with EBSD, TEM has higher resolution. Therefore, TEM based investigation has been carried out to analyze the dislocation microstructures 
under the fatigue. The TEM result was compared with the KAM and GND analysis.

\subsection{Dislocation microstructures after fatigue}

Figure 5 shows the TEM images of dislocation microstructures under different strain amplitudes. Figures $5(\mathrm{a} 1$, b1, c1) are bright field (BF) images, and Figures 5(a2, b2, c2) are dark field (DF) images. By comparing BF and DF images, it is found that the PSBs structure is formed under fatigue loading. At $\varepsilon_{t}=0.3 \%$, a few PSBs can be observed in Figure. 5(a1), and there are many dislocation cells inside the PSBs. The width of PSBs is about $1.1 \mu \mathrm{m}$ and the length of PSBs ranges from several microns to tens of microns, which is much higher than the diameter of cells (less than $1 \mu \mathrm{m}$ ). Some PSBs spans the whole grain, while the cell structure is located inside the grain. At $\varepsilon_{\mathrm{t}}=0.6 \%$ and $0.9 \%$, more PSBs are formed, and the width is significantly reduced to $0.33 \mu \mathrm{m}$ and $0.20 \mu \mathrm{m}$, respectively. At $\varepsilon_{t}=0.9 \%$, PSBs are observed to cross each other, which is caused by dislocation double slip. In Figures 5 (a1, b1), the interaction between PSBs and GBs is observed, and PSBs end at the GBs or continues to expand after passing through the GBs. Under the high temperature LCF of TP347H ASS, a large amount of PSBs is attributed to dislocation planar slip. DSA effect enhances the dislocation plane slip due to the pinning of solute atoms on movable dislocations ${ }^{9,10,22,32}$. At the same time, DSA effect increases with the increase of strain amplitude ${ }^{25}$.

Figure 6 shows the TEM images of the dislocation cells structure. At $\varepsilon_{\mathrm{t}}=0.3 \%$, imperfect cells (Figure 6(a1)) and cells (Figure 6(a2)) are formed. At $\varepsilon_{\mathrm{t}}=0.6 \%$ and $0.9 \%$, a large number of cells are formed. The dislocation density in cells is low, which is high in cell wall.

Cell structures also occur during LCF testing of $316 \mathrm{H}$ ASS at high-temperature ${ }^{33}$. The size of cells decreases with the increase of strain amplitude, as shown in Figure 7. This indicates that the dislocation density is getting higher at the higher strain amplitudes, which is consistent with the results of KAM and GND density as shown in Figure 4. In ferritic steel $^{34}$, SS400 structural steel ${ }^{2}$, and $\mathrm{ASS}^{4}$, with the increase of strain amplitudes, the dislocations density in the specimens under cyclic loading tends to increase due to the progressive reduction of the dislocation cell size $\mathrm{s}^{35}$.

The cell structure formed by dislocations crossslipping in the interiors of the grains had low boundary misorientations from $6^{\circ}$ to $15^{\circ}$, confirmed by the selected area electron diffraction (SAED) pattern in Figure 6(a3, b3). In Figure 6(c3), the new grains or subgrains with clear boundaries are observed. The SAED pattern of Figure 6(c3) contains rings of diffraction spots, which suggests that many of the boundaries have high misorientation angles but the rings are discontinuous and confirms the existence of some low-angle boundaries. This indicates that under high strain amplitude, the austenite grains have undergone dynamic recovery and subgrains formation, while the dynamic recrystallization has not occurred due to insufficient $\operatorname{strain}^{36}$.

\subsection{GND density and the size of dislocation microstructures}

Figures 5-6 show the highly non-uniform distribution of PSBs and cell structures, indicating high strain localization in the fatigue samples. The regions of cells ${ }^{21}$ and PSBs zone ${ }^{9,37}$ are easy to result in fatigue crack initiation.

Figure 7 shows the distribution of mean PSBs width and cell diameter under different strain amplitudes. Smaller the cell diameter, higher will be the dislocation density. At the same time, with the increase of PSBs number and the decrease of mean width, the deformation localization is more significant and the more dislocations will be formed. The superposition between cells and PSBs leads to the increase of dislocation density at high strain amplitude, which is consistent with the results of KAM and GND as shown in Figure 4. Their relationships between the microstructure size and GND density are plotted in Figure 8. By comparing the values of mean cell diameter $\left(d_{\text {cell }}\right)$, mean

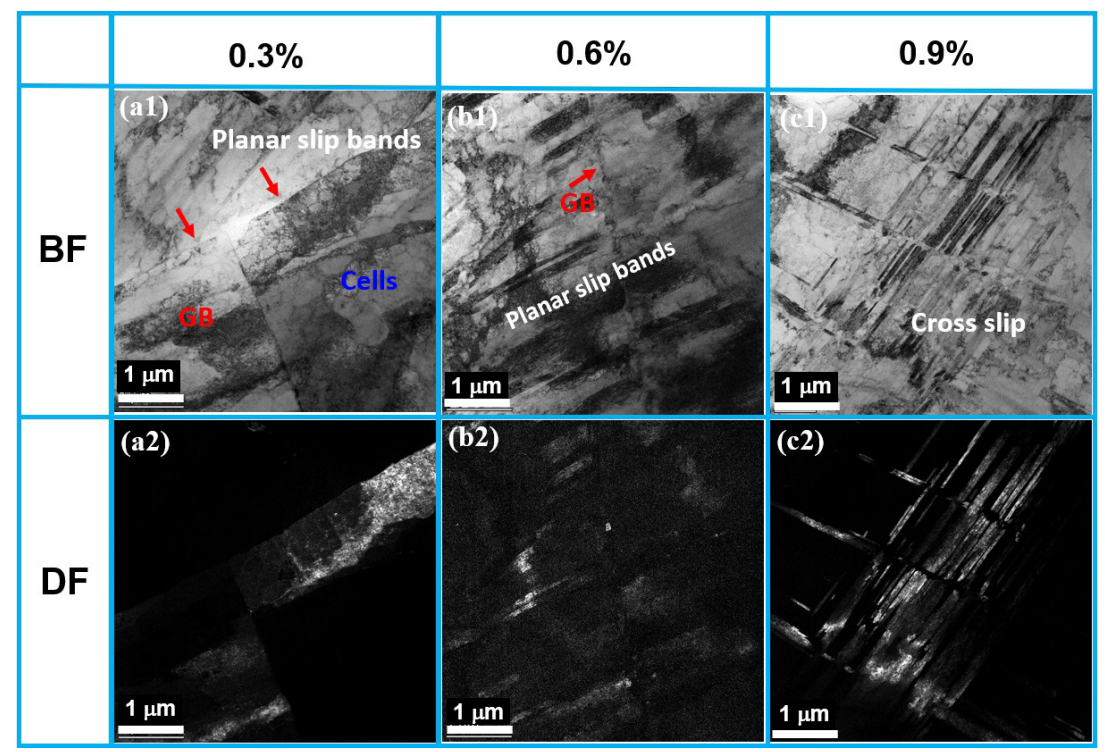

Figure 5. TEM images of PSBs in the fractured samples, (a1) and (a2) $\Delta \varepsilon_{\mathrm{t}}=0.3 \%$; (b1) and (b2) $0.6 \%$; (c1) and (c2) $0.9 \%$. 


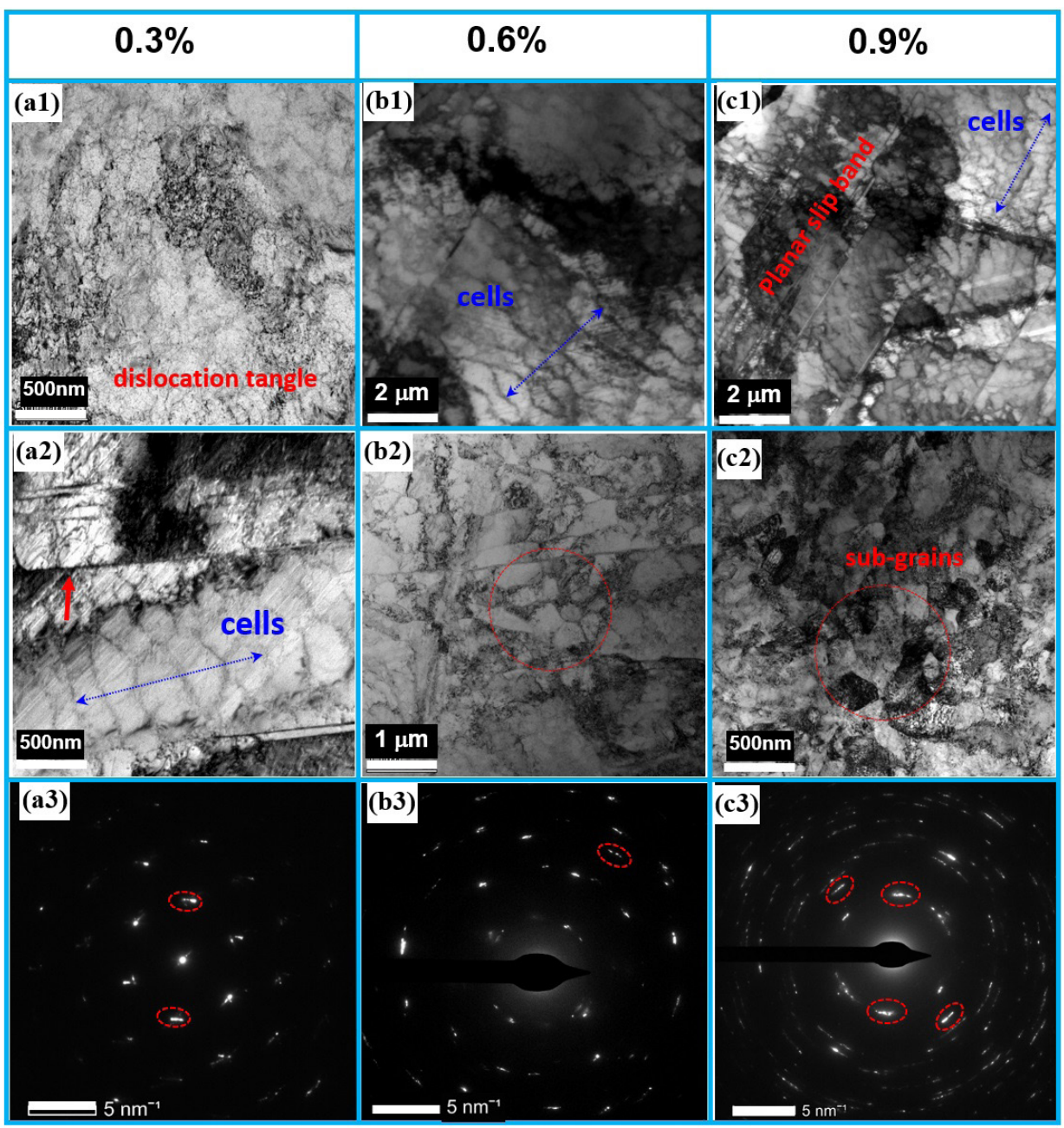

Figure 6. TEM images of cell structures in the fractured samples. (a1-a2) TEM images and (a3) SAED pattern of the cell in (a2); (b1-b2) TEM images and (b3) SAED pattern of the cell in (b2); (c1-c2) TEM images and (c3) SAED pattern of the cell in (c2).

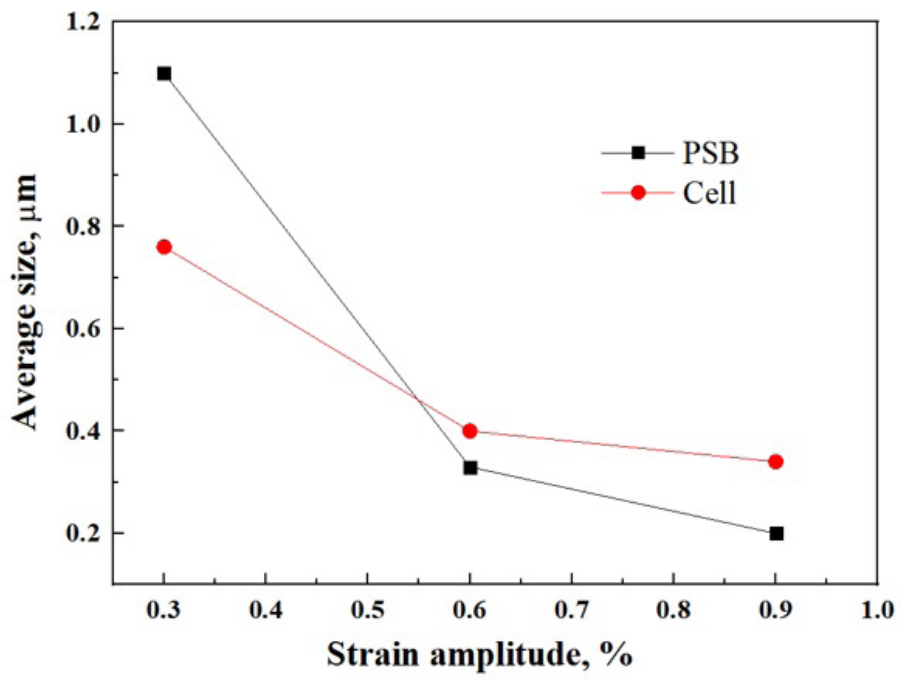

Figure 7. Mean size of PSBs width and cells diameter with the different strain amplitudes. 

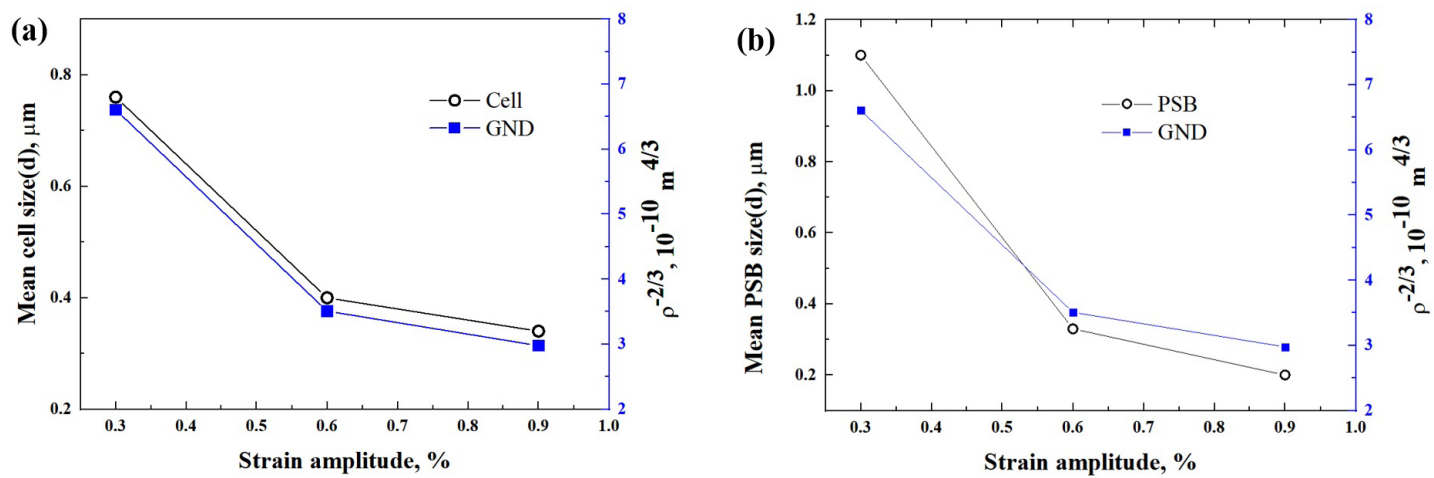

Figure 8. GND density dependence on the mean size of dislocation microstructures under the different strain amplitudes. (a) GND density and cells, (b) GND density and PSBs.

PSBs width $\left(d_{\mathrm{PSB}}\right)$, and GND density $\left(\rho^{\mathrm{GND}}\right)$, it is found that $d_{\text {cell }}$ has a close linear relationship with $\left(\rho^{\mathrm{GND}}\right)^{-2 / 3}$ as shown in Figure $8(\mathrm{a})$, while $d_{\mathrm{PSB}}$ and $\left(\rho^{\mathrm{GND}}\right)^{-2 / 3}$ have the same trend with a nonlinear relationship, as shown in Figure 8(b). It is difficult to quantitatively establish the functional relationship between $d_{\mathrm{PSB}}$ and $\rho^{\mathrm{GND}}$. The GND is known to be proportional to the average value of $\operatorname{KAM}(\theta)$ in Equation $(1)^{15,20}$. This indicates that if two parameters $u$ and $b$ are fixed during EBSD testing, $d_{\text {cell }}$ is also proportional to $\theta^{-2 / 3}$.

\section{Conclusions}

KAM, GND density and dislocation structures of TP $347 \mathrm{H}$ austenitic stainless steel under low cycle fatigue (LCF) was studied at $600^{\circ} \mathrm{C}$, while the total strain amplitude was ranged from $0.3 \%$ to $0.9 \%$.

(1) The results based on EBSD analysis show that the GND density in fatigue specimens gradually increases with the increase of strain amplitude.

(2) Under LCF loading, the dislocation structures are mainly planar slip bands (PSBs) and cell structure. With the increase of strain amplitude, the number of PSBs increases and the width decreases, while the average diameter of cells also decreases. The PSBs originate from the dynamic strain aging (DSA) effect, and DSA is more significant under the high strain amplitude.

(3) There are two ways of dislocation planar slip. Under low strain amplitude, dislocation is dominated by the single slip. With the increase of strain amplitude, a large number of dislocation double slip is appeared.

(4) The average diameter of cells $\left(d_{\text {cell }}\right)$ and PSBs width $\left(d_{\mathrm{PSB}}\right)$ have a specific relationship with GND density $\left(\rho^{\mathrm{GND}}\right)$ under LCF loading of TP347H steel samples. The functional relationships are that $d_{\text {cell }}$ has a close linear relationship with $\left(\rho^{\mathrm{GND}}\right)^{-2 / 3}$, while $d_{\mathrm{PSB}}$ and $\left(\rho^{\mathrm{GND}}\right)^{-2 / 3}$ have the same trend, but a nonlinear relationship.

\section{Acknowledgments}

The authors thank the financial support of the National Natural Science Foundation of China (No. 51874001), Natural Science Foundation of Anhui Province (2008085ME127), and the University Natural Science Research Project of
Anhui Province (KJ2020A0252). and Innovation and Entrepreneurship Training Project of Anhui Province for College Students (S201910360191).

\section{References}

1. Man J, Smaga M, Kuběna I, Eifler D, Polák J. Effect of metallurgical variables on the austenite stability in fatigued AISI 304 type steels. Eng Fract Mech. 2017;185:139-59. http:// dx.doi.org/10.1016/j.engfracmech.2017.04.041.

2. Nguyen N-V, Pham T-H, Kim S-E. Strain rate sensitivity behavior of a structural steel during low-cycle fatigue investigated using indentation. Mater Sci Eng A. 2019;744:490-9. http://dx.doi. org/10.1016/j.msea.2018.12.025.

3. Kundu A, Field DP, Chandra Chakraborti P. Effect of strain and strain rate on the development of deformation heterogeneity during tensile deformation of a solution annealed $304 \mathrm{LN}$ austenitic stainless steel: an EBSD study. Mater Sci Eng A. 2020;773:138854. http://dx.doi.org/10.1016/j.msea.2019.138854.

4. Das A. Dislocation configurations through austenite grain misorientations. Int J Fatigue. 2015;70:473-9. http://dx.doi. org/10.1016/j.ijfatigue.2014.06.012.

5. Wang H, Du H, Wei Y, Hou L, Liu X, Wei H, et al. Precipitation and properties at elevated temperature in austenitic heat-resistant steels: a review. Steel Res Int. 2021;92:2000378. http://dx.doi. org/10.1002/srin.202000378.

6. Sarkar A, Nagesha A, Parameswaran P, Sandhya R, Laha $\mathrm{K}$, Okazaki M. Investigation of fracture mechanisms and substructural changes under sequential fatigue cycling involving LCF and HCF loads in a type $316 \mathrm{LN}$ stainless steel at $923 \mathrm{~K}$. Mater Sci Eng A. 2017;702:360-70. http://dx.doi.org/10.1016/j. msea.2017.07.016.

7. Li P, Li SX, Wang ZG, Zhang ZF. Fundamental factors on formation mechanism of dislocation arrangements in cyclically deformed fcc single crystals. Prog Mater Sci. 2011;56:328-77. http://dx.doi.org/10.1016/j.pmatsci.2010.12.001.

8. Kundu A, Field DP, Chandra Chakraborti P. Influence of strain amplitude on the development of dislocation structure during cyclic plastic deformation of $304 \mathrm{LN}$ austenitic stainless steel. Mater Sci Eng A. 2019;762:138090. http://dx.doi.org/10.1016/j. msea.2019.138090.

9. Zhou HW, Zhang HY, Bai FM, Song M, Chen Y, Zhang LQ, et al. Planar dislocation structure during creep-fatigue interactions of TP347H heat-resistant austenitic steel at $600{ }^{\circ} \mathrm{C}$. Mater Sci Eng A. 2020;779:139141. http://dx.doi.org/10.1016/j. msea.2020.139141.

10. Gerland M, Alain R, Ait Saadi B, Mendez J. Low cycle fatigue behaviour in vacuum of a 316L-type austenitic stainless steel between 20 and $600^{\circ} \mathrm{C}$ Part II: dislocation structure evolution and 
correlation with cyclic behaviour. Mater Sci Eng A. 1997;229:6886. http://dx.doi.org/10.1016/s0921-5093(96)10560-8.

11. Yvell K, Grehk TM, Engberg G. Microstructure characterization of $316 \mathrm{~L}$ deformed at high strain rates using EBSD. Mater Charact. 2016;122:14-21. http://dx.doi.org/10.1016/j.matchar.2016.10.017.

12. Yvell K, Grehk TM, Hedström P, Borgenstam A, Engberg G. Microstructure development in a high-nickel austenitic stainless steel using EBSD during in situ tensile deformation. Mater Charact. 2018;135:228-37. http://dx.doi.org/10.1016/j. matchar.2017.11.046.

13. Ali N, Zhang L, Zhou H, Zhao A, Zhang C, Fu K, et al. Effect of soft reduction technique on microstructure and toughness of medium carbon steel. Materials Today Communications. 2021;26:102130. http://dx.doi.org/10.1016/j.mtcomm.2021.102130.

14. Ali N, Zhang L, Zhou H, Zhao A, Zhang C, Fu K, et al. Investigation on Internal crack defects in medium carbon steel by soft reduction. Mater Res. 2021;24:e20210055. http://dx.doi. org/10.1590/1980-5373-MR-2021-0055.

15. Ma X, Huang C, Moering J, Ruppert M, Höppel HW, Göken $\mathrm{M}$, et al. Mechanical properties of copper/bronze laminates: role of interfaces. Acta Mater. 2016;116:43-52. http://dx.doi. org/10.1016/j.actamat.2016.06.023.

16. Rui S-S, Shang Y-B, Fan Y-N, Han Q-N, Niu L-S, Shi H-J, et al. EBSD analysis of creep deformation induced grain lattice distortion: a new method for creep damage evaluation of austenitic stainless steels. Mater Sci Eng A. 2018;733:329-37. http://dx.doi.org/10.1016/j.msea.2018.07.058.

17. Schayes C, Bouquerel J, Vogt J-B, Palleschi F, Zaefferer S. A comparison of EBSD based strain indicators for the study of Fe-3Si steel subjected to cyclic loading. Mater Charact. 2016;115:61-70. http://dx.doi.org/10.1016/j.matchar.2016.03.020.

18. Bouquerel J, Delbove M, Vogt JB. Advanced processing of EBSD data to distinguish the complex microstructure evolution of a $\mathrm{Cu}-\mathrm{Ni}$-Si alloy induced by fatigue. Mater Charact. 2018;145:55662. http://dx.doi.org/10.1016/j.matchar.2018.09.017.

19. Kakimoto R, Koyama M, Tsuzaki K. EBSD- and ECCI-based assessments of inhomogeneous plastic strain evolution coupled with digital image correlation. ISIJ Int. 2019;59:2334-42. http:// dx.doi.org/10.2355/isijinternational.ISIJINT-2019-232.

20. Xiao B, Xu L, Zhao L, Jing H, Han Y, Song K. Transient creep behavior of a novel tempered martensite ferritic steel G115. Mater Sci Eng A. 2018;716:284-95. http://dx.doi.org/10.1016/j. msea.2018.01.047.

21. Sarkar A, Dash MK, Nagesha A, Dasgupta A, Sandhya R, Okazaki M. EBSD based studies on various modes of cyclic deformation at $923 \mathrm{~K}$ in a type $316 \mathrm{LN}$ stainless steel. Mater Sci Eng A. 2018;723:229-37. http://dx.doi.org/10.1016/j. msea.2018.02.101

22. Zhou HW, Bai FM, Yang L, Wei HL, Chen Y, Peng GS, et al. Mechanism of dynamic strain aging in a niobium-stabilized austenitic stainless steel. Metall Mater Trans, A Phys Metall Mater Sci. 2018;49:1202-10. http://dx.doi.org/10.1007/s11661018-4498-2.

23. Zhou HW, He YZ, Cen YW, Jiang JQ. Low-cycle fatigue behavior of TP347H austenitic stainless steels at room temperature. Adv Mater Res. 2013;815:875-9. http://dx.doi.org/10.4028/www. scientific.net/AMR.815.875.
24. Zhou HW. Study on high temperature low-cycle fatigue behavior for steels used ultra-super critical boilers (Academic Degree of Doctor of Engineering). China: Southeast University; 2015.

25. Zhou HW, He YZ, Cui M, Cen YW, Jiang JQ. Dependence of dynamic strain ageing on strain amplitudes during the low-cycle fatigue of TP347H austenitic stainless steel at 550 ${ }^{\circ} \mathrm{C}$. Int J Fatigue. 2013;56:1-7. http://dx.doi.org/10.1016/j. ijfatigue.2013.07.010.

26. Hong SG, Lee KO, Lee SB. Dynamic strain aging effect on the fatigue resistance of type $316 \mathrm{~L}$ stainless steel. Int J Fatigue. 2005;27:1420-4. http://dx.doi.org/10.1016/j.ijfatigue.2005.06.037.

27. Fournier B, Sauzay M, Caës C, Noblecourt M, Mottot M, Bougault $\mathrm{A}$, et al. Creep-fatigue-oxidation interactions in a 9Cr-1Mo martensitic steel. Part II: effect of compressive holding period on fatigue lifetime. Int J Fatigue. 2008;30:663-76. http:// dx.doi.org/10.1016/j.ijfatigue.2007.05.008.

28. Prasad Reddy GV, Sandhya R, Sankaran S, Mathew MD. Low cycle fatigue behavior of $316 \mathrm{LN}$ stainless steel alloyed with varying nitrogen content. Part II: fatigue life and fracture behavior. Metall Mater Trans, A Phys Metall Mater Sci. 2014;45:5057-67. http://dx.doi.org/10.1007/s11661-014-2429-4.

29. Zohrevand M, Aghaie-Khafri, M, Forouzan, F, Vuorinen E. Microstructural evolutions under ultrasonic treatment in 304 and 316 austenitic stainless steels: impact of stacking fault energy. Steel Res Int. 2021:92(9):2100041. http://dx.doi.org/10.1002/ srin.202100041.

30. Jang M-H, Kang J-Y, Jang JH, Lee T-H, Lee C. Microstructure control to improve creep strength of alumina-forming austenitic heat-resistant steel by pre-strain. Mater Charact. 2018;137:1-8. http://dx.doi.org/10.1016/j.matchar.2018.01.005.

31. Li H, Jing H, Xu L, Han Y, Zhao L, Tang Z, et al. Microstructure mechanism, cyclic deformation behavior of an Fe-Ni-Cr alloy considering non-Masing behavior. Int J Fatigue. 2019;127:53750. http://dx.doi.org/10.1016/j.ijfatigue.2019.06.035.

32. Hongwei Z, Yizhu H, Jizu L, Sixian R. Study on dynamic strain aging and low-cycle fatigue of stainless steel in ultrasupercritical unit. Energy Mater Conf Proc. 2014:299-306.

33. Xu L, Bao F, Zhao L, Han Y, Jing H, Yu H, Gong X. Characterizing microstructural evolution and low cycle fatigue behavior of $316 \mathrm{H}$ austenitic steel at high-temperatures. J Nucl Mater. 2021;546. http://dx.doi.org/10.1016/j.jnucmat.2020.152758.

34. Vogt JB, Bouquerel J, Léaux F, Palleschi F. Fatigue damage assessment of alternator fans by EBSD. Procedia Eng. 2013;66:608-14. http://dx.doi.org/10.1016/j.proeng.2013.12.112.

35. Ye D, Matsuoka S, Nagashima N. Determination of fatigue mesoscopic mechanical properties of an austenitic stainless steel using depth-sensing indentation (DSI) technique. Mater Sci Eng A. 2007;456:120-9. http://dx.doi.org/10.1016/j. msea.2006.12.026.

36. Zheng Y, Li B, Li Q, Liu C, Chen X. Ratcheting deformation behavior of $316 \mathrm{LN}$ stainless steel under thermomechanical and isothermal loadings. Int J Fatigue. 2020;138:105718. http:// dx.doi.org/10.1016/j.ijfatigue.2020.105718.

37. Verma VK, Koyama M, Hamada S, Akiyama E. Multiple damage mechanisms facilitated by planar dislocation glide in a commercial-grade precipitation-strengthened $\mathrm{Fe}-\mathrm{Ni}-\mathrm{Cr}$ based steel. Mater Sci Eng A. 2020;782:139250. http://dx.doi. org/10.1016/j.msea.2020.139250. 